\title{
Investigation of physicochemical characteristics and heavy metal distribution profile in groundwater system around the open dump site
}

\author{
S. Kanmani · R. Gandhimathi
}

Received: 23 November 2012/ Accepted: 8 February 2013/Published online: 20 February 2013

(C) The Author(s) 2013. This article is published with open access at Springerlink.com

\begin{abstract}
In this study, the characterization of solid waste and the effect of the leachate from an open dumping site in Ariyamangalam, Tiruchirappalli District, Tamil Nadu, on groundwater is investigated. A total of 14 groundwater samples and 20 leachate samples were collected for monitoring purpose. All the samples were analyzed for various physical and chemical parameters according to standard methods: this includes $\mathrm{pH}$, electrical conductivity, total dissolved solids (TDS), total hardness, and total alkalinity, major cations such as $\mathrm{Ca}^{2+}, \mathrm{Mg}^{2+}$, and $\mathrm{Fe}^{2+}$, major anions such as $\mathrm{NO}_{3}{ }^{-}, \mathrm{Cl}^{-}$, and $\mathrm{SO}_{4}{ }^{2-}$ and heavy metals such as $\mathrm{Cd}, \mathrm{Cu}, \mathrm{Mn}, \mathrm{Pb}$, and $\mathrm{Zn}$. The results indicated that, very few parameters such as $\mathrm{pH}$, sulfates and nitrates concentration in the groundwater samples are within the recommended maximum admissible limits approved by WHO (World Health Organization 940-949, 2002) and Bureau of Indian standards (IS 10500:1991). The TDS (range between 740 and $14,200 \mathrm{mg} / \mathrm{L}$ ) in groundwater reveal the saline behavior of water and was found to be very high according to standards. The range of chlorides in all the locations under investigation is $215.15-4,098.73 \mathrm{mg} / \mathrm{L}$. The contour plots also indicated that the groundwater was rigorously contaminated with various heavy metals. The presence of high concentration of $\mathrm{Pb}(0.59 \mathrm{mg} / \mathrm{L})$ in groundwater samples nearby dumping site implies that groundwater samples were contaminated by leachate migration from an open dumping site.
\end{abstract}

Keywords Groundwater - Leachate - Pollution · Solid waste

S. Kanmani · R. Gandhimathi $(\bowtie)$

Department of Civil Engineering, National Institute of Technology, Tiruchirappalli, Tamil Nadu, India e-mail: rgmathii@nitt.edu

\section{Introduction}

The generation of solid waste has become an increasing environmental and public health problem everywhere in the world, particularly in developing countries. The fast expansion of urban, agricultural and industrial activities spurred by rapid population growth and the change in consumer habits has produced vast amounts of solid wastes (Akoteyon et al. 2011). Open dumps are the oldest and the most common way of disposing of solid waste. In recent years thousands have been closed, while many still are being used. In many cases, they are located wherever land is available, without regard to safety, health hazard and esthetic degradation. The waste is often piled as high as equipment allows. In some instances, the refuse is ignited and allowed to burn. In others, the refuse is periodically leveled and compacted (Sabahi et al. 2009). The dumping of solid waste in uncontrolled landfills can cause significant impacts on the environment and human health (Dong et al. 2008). The most commonly reported danger to the human health from these landfills is from the use of groundwater that has been contaminated by leachate (Jhamnani and Singh 2009).

Leachate is produced when moisture enters the refuse in a landfill, extracts contaminants into the liquid phase, and produces moisture content sufficiently high to initiate liquid flow. Leachate is generated in a landfill as a consequence of the contact of water with solid waste (Lo 1996). Leachate from a solid waste disposal site is generally found to contain major elements like calcium, magnesium, potassium, nitrogen and ammonia, trace metals like iron, copper, manganese, chromium, nickel, lead and organic compounds like phenols, polyaromatic hydrocarbons, acetone, benzene, toluene, chloroform, etc. (Freeze and Cherry 1979). The concentration of these in the 
leachate and water depends on the composition of wastes (Alker et al. 1995). The rate and characteristics of leachate produced depends on many factors such as solid waste composition, particle size, degree of compaction, hydrology of site, age of landfill, moisture and temperature conditions, and available oxygen. Leachate tended to migrate in surrounding soil may result in contamination of underlying soil and groundwater (Jhamnani and Singh 2009). Leachate migrations from waste sites or landfills and the release of pollutants from sediment (under certain conditions) pose a high risk to groundwater resource if not adequately managed. Their impact on groundwater continues to raise concern and have become the subject of recent and past investigations (Ahmed and Sulaiman 2001; Fatta et al. 1999; Kjelsen et al. 1998; Bjerg et al. 1995; Robinson and Gronow 1992; Cariera and Masciopinto 1998; Loizidou and Kapetanios 1993; Gallorini et al. 1993; Khan et al. 1990; Kunkle and Shade 1976). Empirical investigations as well as modeling techniques (McCreanor and Reinhart 2000; Lee et al. 1997; Syriopoulou and Koussis 1987; Koussis et al. 1989; Ostendorf et al. 1984) have been used to assess the pollution of groundwater by leachate from a landfill.

Groundwater is an important source of drinking water for humankind. It contains over $90 \%$ of the fresh water resources and is an important reserve of good quality water. Groundwater, like any other water resource, is not just of public health and economic value; it also has an important ecological function (Armon and Kitty 1994). The chemical composition of groundwater is a measure of its suitability as a source of water for human and animal consumption, irrigation, and for industrial and other purposes (Babiker et al. 2007). Therefore, monitoring the quality of water is important because clean water is necessary for human health and the reliability of aquatic ecosystems.

This study aims to develop an understanding of the natural groundwater quality in the Ariyamangalam open dumping site and the adjacent areas through the dug wells and bore wells that have been selected for this purpose. To estimate how far groundwater quality has been affected by the downward movement of leachate from the Ariyamangalam open dumping site, the surrounding groundwater samples were collected and analyzed for various physicochemical parameters. The heavy metals distribution profile in the groundwater system at the waste disposal site was also studied.

\section{Study area}

Tiruchirappalli, better called as Trichy, is the fourth largest municipal corporation in Tamil Nadu and also the fourth largest urban agglomeration in the state. Kaveri River flows through the length of the district and is the principal source of irrigation and water supply. The district has an area of
$4,404 \mathrm{~km}^{2}$. The district has an approximate population of 27 lakhs and the population density of 602 inhabitants per square kilometer. The maximum temperature experienced in this district is $37.7{ }^{\circ} \mathrm{C}$ and the minimum temperature is $18.9^{\circ} \mathrm{C}$. The normal annual rainfall is $842.60 \mathrm{~mm}$. The Trichy district is served by an open dumping yard namely Ariyamangalam garbage ground located $12 \mathrm{~km}$ from the city on the Trichy-Thanjavur highway. The dumping site is located at $10^{\circ} 48^{\prime} \mathrm{N}$ and $78^{\circ} 43^{\prime} \mathrm{E}$. The ground elevation of the dumping site is $75.875 \mathrm{~m}$ above mean sea level. The Ariyamangalam dumping site has been in operation since 1967, covering a total surface area of 47.7 acres where the geological formation consists of mainly alluvium (based on the data collected from Public Works Department, Tamilnadu). The Tiruchirappalli municipal corporation consists of four zones namely Srirangam, Ponmalai, Ariyamangalam, and Abishegapuram. The dump site receives approximately 400-470 tonnes of MSW per day, which are collected from four zones. The height of dump is around 3-4 $\mathrm{m}$ above ground level. The waste is disposed here without segregation and compaction. The deposited waste is not provided by any daily or intermediate covers. No lining is provided at the bottom of the dump yard to prevent leachate migration. Access to the site is freely available to all and the site is regularly utilized by rag pickers, scavenging for recyclable materials, and by a variety of animals including water buffaloes, cattle, pigs, and dogs scavenging food waste. Unhygienic drinking water and garbageinduced diseases, like dysentery, cholera and hepatitis, are frequently reported in the surrounding villages. The layout of the study area is shown in Fig. 1.

\section{Methodology}

Solid waste composition

To appraise the fresh solid waste composition, a total of 60 fresh solid waste samples (three samples from each zone per day) from four different zones of Trichy city were collected for 5 days from the truck discharge point to the dumping site. The collected fresh solid waste were segregated into different categories viz. paper, plastics, metals, glass, debris, vegetables, textiles, etc. The segregated samples were weighed individually (Mohan and Gandhimathi 2009). The mean of the solid waste composition was calculated using the results of the composition of each of the sorting samples (Gidarakos et al. 2005).

Sampling of leachate and groundwater

Leachate samples from the actual leachate streams in the solid waste dumping site were collected in $5 \mathrm{~L}$ 


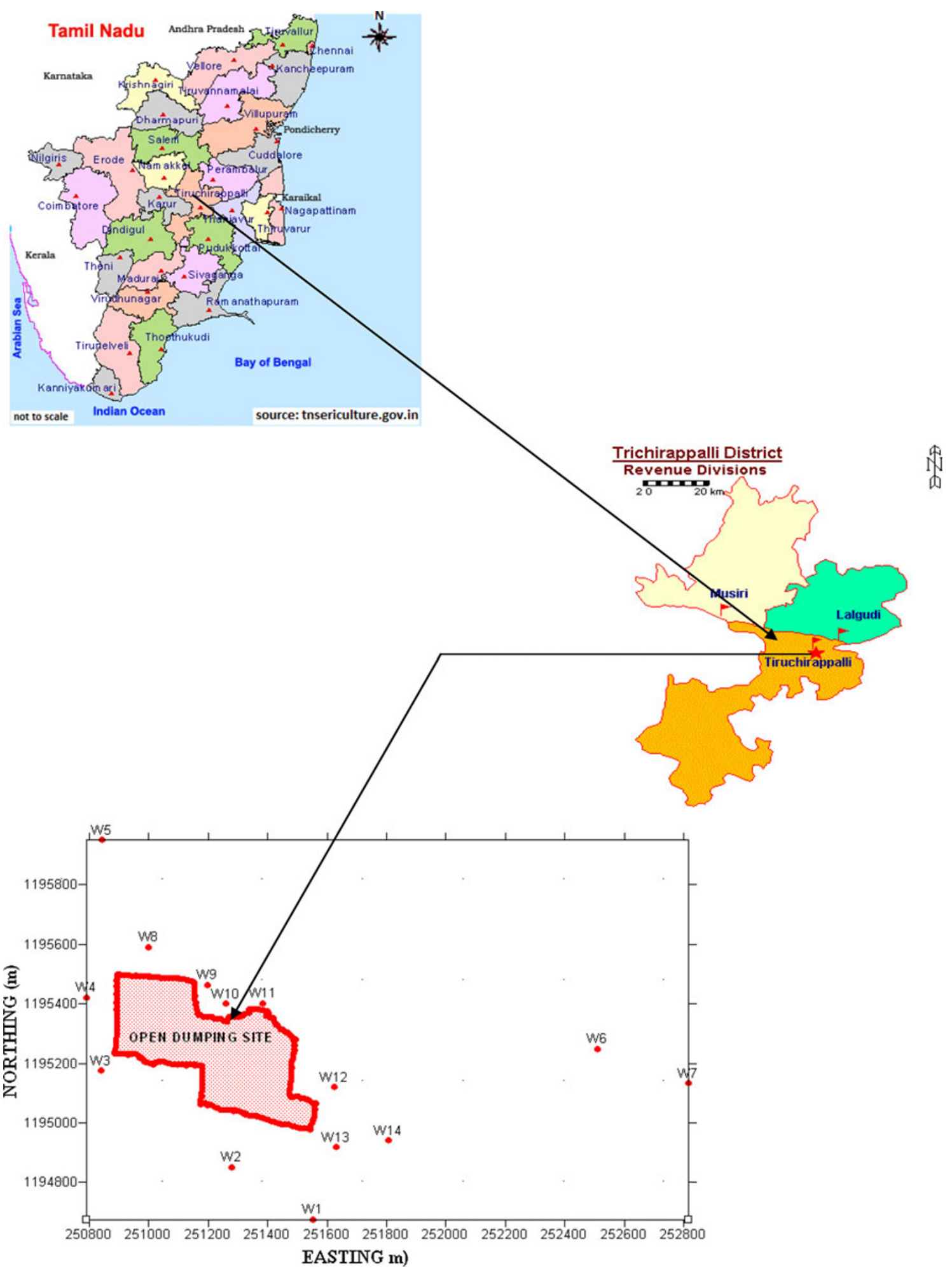

Fig. 1 Study area with groundwater sampling locations

polypropylene carboys that were rinsed out thrice prior to sample collection, transported to the laboratory, stored at $4{ }^{\circ} \mathrm{C}$ and analyzed within 2 days. A total of 20 leachate samples were collected for monitoring purpose, out of which 11 samples were collected from the old dumping area (greater than 3 years old) referred to as "stabilized 
leachate" whereas the remaining nine samples of leachate called as "fresh leachate" were collected near the new dumping area (less than or equal to 2 years old). The physicochemical analyses were carried out according to the standard methods (APHA 1998). A random sampling method was employed to collect the groundwater samples with due consideration to represent land-use patterns, topography, and areas close to dumping site (Kale et al. 2010). Groundwater samples of totally 14 numbers (4 hand pumps, 7 bore wells and 3 open wells) were collected within $1.7 \mathrm{~km}$ from the dumping site. The details of groundwater sampling locations are given in Table 1. The spatial data was obtained from the data recorded by a Garmin Global Positioning System. The groundwater sampling locations with the study area is shown in Fig. 1. Water was collected from open wells using drawing buckets tied with ropes, while bore wells and tube wells were pumped for 5-15 min before sampling (Andrew et al. 2011). These samples were collected in pre-cleaned polypropylene containers of $2 \mathrm{~L}$ capacity after rinsing with the sample and preserved airtight to avoid evaporation, stored at $4{ }^{\circ} \mathrm{C}$ and analyzed within 2 days.

The $\mathrm{pH}$ and electrical conductivity (EC) were recorded on site at the time of sampling with digital $\mathrm{pH}$ meter and digital EC meter, respectively. For heavy metal analyses, samples were separately collected in pre-washed polypropylene containers of $100 \mathrm{ml}$ capacity and acidified onsite to avoid precipitation of metals.

\section{Analytical methods}

The parameters were selected based on their relative importance in municipal landfill leachates composition, and their pollution potential on groundwater resource in particular (Bagchi 2004). The physicochemical parameters such as total dissolved solids (TDS), total alkalinity (TA), total hardness (TH), major cations such as calcium $\left(\mathrm{Ca}^{2+}\right)$ and magnesium $\left(\mathrm{Mg}^{2+}\right)$, major anion such as chlorides $\left(\mathrm{Cl}^{-}\right)$of the leachate and groundwater samples were analyzed by titrimetric methods. Chloride was included in the water quality assessment because of its measure of extent of dispersion of leachates in groundwater body (Chapman 1992). Sulfates $\left(\mathrm{SO}_{4}{ }^{2-}\right)$ in the groundwater samples were analyzed by nephelometric turbidity method (APHA 1998). Nitrates $\left(\mathrm{NO}_{3}{ }^{-}\right.$) and total organic carbon (TOC) determination in the groundwater samples were carried out by DR 2700 spectrometer. Estimation of chemical oxygen demand (COD) was done by closed reflux titrimetry method, while biochemical oxygen demand (BOD) was calculated by oxygen determination by Winkler titration for the preserved leachate sample. All the analyses in this study were repeated two or three times until concordant values were obtained, and all the tests were carried out according to the standard methods (APHA 1998). The data was statistically analyzed by setting up and calculating a correlation matrix for the various parameters using Statistical Package for Social Sciences (SPSS) software package (Norusis 1997).

The heavy metals such as $\mathrm{Cd}, \mathrm{Cu}, \mathrm{Mn}, \mathrm{Pb}$ and $\mathrm{Zn}$ concentrations in the leachate and ground water samples were analyzed using atomic absorption spectrophotometer (AAS) supplied by Thermo Fisher Scientific, USA with D2 background correction lamp. Standard solutions of heavy metals viz. copper $(\mathrm{Cu})$, cadmium $(\mathrm{Cd})$, manganese $(\mathrm{Mn})$, lead $(\mathrm{Pb})$ and zinc $(\mathrm{Zn})$ were prepared with distilled water using copper sulfate $\left(\mathrm{CuSO}_{4} \cdot 5 \mathrm{H}_{2} \mathrm{O}\right)$, cadmium sulfate $\left(\mathrm{CdSO}_{4} \cdot 8 \mathrm{H}_{2} \mathrm{O}\right)$, manganese sulfate $\left(\mathrm{MnSO}_{4} \cdot 7 \mathrm{H}_{2} \mathrm{O}\right)$, lead nitrate $\left[\mathrm{Pb}\left(\mathrm{NO}_{3}\right)_{2}\right]$, and zinc nitrate $\left[\mathrm{Zn}\left(\mathrm{NO}_{3}\right)_{2}\right.$ $\left.\cdot 6 \mathrm{H}_{2} \mathrm{O}\right]$.
Table 1 Details of sampling wells

\begin{tabular}{lllll}
\hline Well No. & Type of well & Northing $(\mathrm{m})$ & Easting $(\mathrm{m})$ & Distance $(\mathrm{km})$ \\
\hline 1 & Hand pump & $1,194,676$ & 251,553 & 0.72 \\
2 & Open well & $1,194,850$ & 251,278 & 0.46 \\
3 & Bore well & $1,195,175$ & 250,840 & 0.38 \\
4 & Bore well & $1,195,420$ & 250,790 & 0.43 \\
5 & Hand pump & $1,195,949$ & 250,843 & 0.74 \\
6 & Bore well & $1,195,248$ & 252,510 & 1.31 \\
7 & Hand pump & $1,195,133$ & 252,816 & 1.62 \\
8 & Open well & $1,195,590$ & 251,000 & 0.35 \\
9 & Bore well & $1,195,463$ & 251,197 & 0.16 \\
10 & Open well & $1,195,400$ & 251,260 & 0.12 \\
11 & Bore well & $1,195,401$ & 251,384 & 0.21 \\
12 & Bore well & $1,195,119$ & 251,623 & 0.46 \\
13 & Hand pump & $1,194,917$ & 251,631 & 0.58 \\
14 & Bore well & $1,194,940$ & 251,806 & 0.70 \\
\hline
\end{tabular}




\section{Results and discussion}

Composition of municipal solid waste

The results from the composition studies (Fig. 2) show that samples from Ariyamangalam dumping site contained about $90-95 \%$ combustible materials such as paper, textiles, plastic, debris, metals, glass, and vegetable waste. The non-combustible fraction such as metals and glass is about $1-5 \%$. The results were compared with solid waste composition reported by other researchers. Mohan and Gandhimathi (2009) reported that the MSW composition from Perungudi dumping site (Chennai City, Tamil Nadu) contained about $60-70 \%$ combustible materials such as textile, leaves, plastics, food waste, etc., with an average of $65 \%$. The non-combustible fraction such as metals and glass was about $30-40 \%$ with an average of $35 \%$. The solid waste composition in most Asian countries is highly biodegradable, mainly composed of an organic fraction

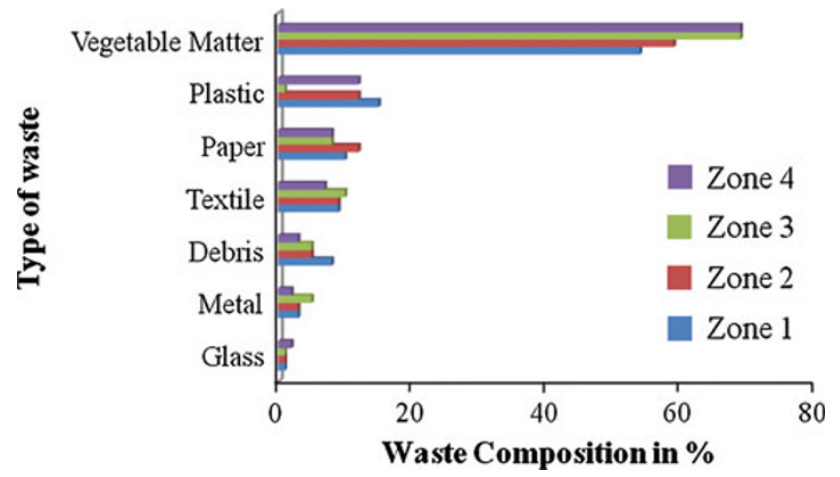

Fig. 2 Fresh solid waste composition with high moisture content (Visvanathan et al. 2004). Joseph et al. (2012) revealed that the biodegradable waste was high when compared to non-biodegradable waste in MSW composition at Chennai city. The findings from other studies indicated that the composition of MSW is sitespecific and based on the nature of waste and source location.

\section{Leachate}

The physicochemical characteristics and the heavy metal contamination in the collected leachate sample depend primarily upon the waste composition and water content of the municipal solid waste (MSW) (Denutsui et al. 2012). The physicochemical characteristics and heavy metal concentrations were analyzed for the collected leachate sample from Ariyamangalam open dumping site and are presented in Table 2.

From the Table 2, it can be observed that the fresh leachate sample possesses very high concentration of chemical parameters except $\mathrm{pH}$, when compared to stabilized leachate samples. The $\mathrm{pH}$ value of the fresh samples was observed in the range of 6.96-7.77, but the older samples were amber colored and alkaline with $\mathrm{pH}$ range from 7.68 to 8.33 . This may be attributed to the decrease in the concentration of free volatile acids due to anaerobic decomposition, as fatty acids can be partially ionized and contribute to higher $\mathrm{pH}$ values. Alkaline $\mathrm{pH}$ is normally encountered at landfills, 10 years after disposal (El-Fadel et al. 2002). The relatively high value of electrical conductivity $(57,000 \mu \mathrm{mho} / \mathrm{cm})$ indicates the presence of dissolved inorganic materials in the samples. The concentration of TDS $(60,970 \mathrm{mg} / \mathrm{L})$ also fluctuates widely. Other
Table 2 Typical range of leachate characteristics
All parameters are expressed in $\mathrm{mg} / \mathrm{L}$ except $\mathrm{pH}$ and $\mathrm{EC}$ (EC is expressed in $\mu \mathrm{mho} / \mathrm{cm}$ )

$B D L$ below detectable limit

\begin{tabular}{clcc}
\hline S. No. & Parameter & Fresh leachate & Stabilized leachate \\
\hline 1 & pH & $6.05-7.77$ & $7.68-8.33$ \\
2 & Total dissolved solids & $10,000-60,970$ & $6,000-29,000$ \\
3 & Electrical conductivity & $11,130-57,000$ & $6,810-40,300$ \\
4 & Chlorides & $1,000-8,000$ & $1,000-6,500$ \\
5 & Total alkalinity & $4,500-26,000$ & $2,500-11,000$ \\
6 & Total hardness & $4,000-17,000$ & $4,500-8,500$ \\
7 & Calcium & $1,200-3,000$ & $400-1,800$ \\
8 & Magnesium & $250-1,500$ & $250-1,100$ \\
9 & BOD & $3,300-43,328$ & $60-3,000$ \\
10 & COD & $6,240-75,840$ & $1,024-19,200$ \\
11 & Iron & $14-600$ & $40-400$ \\
12 & Cadmium & $0.35-1.40$ & BDL-0.16 \\
13 & Copper & $0.85-1.92$ & BDL-0.55 \\
14 & Manganese & $1.79-8.19$ & BDL-1.06 \\
15 & Lead & $1.80-5.15$ & BDL-0.77 \\
16 & Zinc & $0.35-4.80$ & BDL-0.19 \\
\hline
\end{tabular}


inorganic contaminants also follow the trend of decreasing concentrations with increasing leachate age and stability. In general, leachate generated from young acidogenic landfills are characterized by high concentrations of organic and inorganic pollutants (Calli et al. 2005). The presence of Magnesium in the leachate is due to the disposal of construction waste along with MSW (Al-Yaqout 2003). The calcium and magnesium concentrations exhibited typical trends of constituents affected by the biological activity in the dumping site. A reduction with time is attributed to the depletion of these compounds and to the increase in $\mathrm{pH}$, thus reducing their solubility in leachate, and enhancing precipitation. The initial concentrations of these parameters are on the higher side (1,200-3,000 mg/L, 250-1,500 mg/L). A decrease in concentration was observed in stabilized leachate samples. The chloride concentration in the leachate varied from 1,000 to $8,000 \mathrm{mg} / \mathrm{L}$ for young leachate samples and 1,000-6,500 mg/L for stabilized samples. The possible anthropogenic sources of chloride are kitchen wastes from households, restaurants, and hotels. TA varies between 4,500 and $26,000 \mathrm{mg} / \mathrm{L}$. The presence of high BOD $(43,328 \mathrm{mg} / \mathrm{L})$ and COD $(75,840 \mathrm{mg} / \mathrm{L})$ indicates the high organic strength. This indicates that majority of the organic compounds is biodegradable (Fatta et al. 1999). The presence of $\mathrm{Fe}(400 \mathrm{mg} / \mathrm{L})$ in the leachate sample indicates that steel scraps are also dumped in the landfill. The dark brown color of the leachate is mainly attributed to the oxidation of ferrous to ferric form and the formation of ferric hydroxide colloids and complexes with fulvic/humic substance (Chu et al. 1994).

The concentration range of trace elements such as $\mathrm{Cd}$, $\mathrm{Cu}, \mathrm{Fe}, \mathrm{Mn}, \mathrm{Pb}$, and $\mathrm{Zn}$ were found in the collected leachate samples and are also reported in Table 2. Fresh leachate samples showed a higher degree of metal solubilization, due to lower $\mathrm{pH}$ values caused by the biological production of organic fatty acids. As the dumping site age increased, the consequent increase in $\mathrm{pH}$ values caused a certain decrease in metal solubility (Mohan and Gandhimathi 2009). The stabilized leachate samples have less concentration when compared to fresh leachate samples. The concentration of $\mathrm{Zn}(4.80 \mathrm{mg} / \mathrm{L})$ in the leachate shows that the dumping site receives waste from batteries and fluorescent lamps. The presence of $\mathrm{Pb}$ in the leachate samples are in the range $1.85-5.15 \mathrm{mg} / \mathrm{L}$. The possible source of lead may be batteries, chemicals for photograph processing, older lead-based paints and lead pipes disposed at the landfill, which indicates toxicity to all forms of life at this level. Acidity in the leachate causes lead to be released from refuse (Al-Yaqout 2003). $\mathrm{Cd}(1.4 \mathrm{mg} / \mathrm{L})$ and $\mathrm{Cu}$ $(1.92 \mathrm{mg} / \mathrm{L})$ are also present in the leachate samples whereas high $\mathrm{Mn}(8.18 \mathrm{mg} / \mathrm{L})$ concentrations suggest a strong reducing environment. A variety of waste is dumped at Ariyamangalam open dump site, which likely indicate the origin of $\mathrm{Mn}, \mathrm{Pb}, \mathrm{Cu}, \mathrm{Cd}$, and $\mathrm{Fe}$ in leachate.

\section{Groundwater assessment}

The collected groundwater samples in and around the dumping site were free from color and odor excluding the locations W3 and W12. The groundwater of the studied area is used for drinking and domestic purposes. Table 3 shows the desirable and maximum permissible limit of individual species for drinking water recommended by Bureau of Indian Standards (BIS 1991) and World Health Organization (2002). The physicochemical
Table 3 Drinking water quality standards as recommended by BIS and WHO

All values are in $\mathrm{mg} / \mathrm{L}$, except $\mathrm{pH}$

\begin{tabular}{|c|c|c|c|c|}
\hline \multirow[t]{2}{*}{ S. No. } & \multirow[t]{2}{*}{ Parameters } & \multicolumn{2}{|c|}{ BIS standards (IS 10500:1991) } & \multirow{2}{*}{$\begin{array}{l}\text { World Health Organization } \\
\text { (WHO) (2002) }\end{array}$} \\
\hline & & Desirable limit & Permissible limit & \\
\hline 1 & $\mathrm{pH}$ & $6.5-8.5$ & $6.5-8.5$ & $6.5-9.2$ \\
\hline 2 & Total dissolved solids & 300 & 1,500 & 250 \\
\hline 3 & Total alkalinity & 200 & 600 & 500 \\
\hline 4 & Total hardness & 300 & 600 & 300 \\
\hline 5 & Calcium & 75 & 200 & 150 \\
\hline 6 & Magnesium & 30 & 100 & 200 \\
\hline 7 & Chlorides & 250 & 1,000 & 200 \\
\hline 8 & Sulfates & 250 & 400 & 50 \\
\hline 9 & Nitrates & 45 & 45 & 0.5 \\
\hline 10 & Cadmium & 0.01 & No relaxation & 0.005 \\
\hline 11 & Copper & 0.05 & 1.5 & 1 \\
\hline 12 & Iron & 0.3 & 1.0 & 0.3 \\
\hline 13 & Manganese & 0.1 & 0.3 & 0.1 \\
\hline 14 & Lead & 0.05 & No relaxation & 0.05 \\
\hline 15 & Zinc & 5 & 15 & 5 \\
\hline
\end{tabular}


concentrations of collected groundwater samples for the various parameters are shown in Figs. 3, 4, 5. The $\mathrm{pH}$ values of all groundwater samples are within the range of BIS and WHO standards. EC is the indicator of dissolved inorganic ions in groundwater. The presence of EC in the studied area ranges between 802 (W8) and 12,680 (W2) $\mu \mathrm{mho} / \mathrm{cm}$ and was found to be high, especially at locations W1, W2, W3, and W9. These high conductivity values measured in the underground water near the dumping site are an indication of its effect on groundwater. The TDS in groundwater reveal the saline behavior of water. According to classification by Rabinove et al. (1958), two samples were non saline (TDS value less than $1,000 \mathrm{mg} / \mathrm{L})$; nine samples were in the slightly saline category (TDS value range between 1,000 and $3,000 \mathrm{mg} / \mathrm{L}$ ) and two samples were in moderately saline category (TDS value range between 3,000 and $10,000 \mathrm{mg} / \mathrm{L}$ ). Only one sample was very saline in nature (W2) with the value exceeding $10,000 \mathrm{mg} / \mathrm{L}$. This high value of TDS may be due to the leaching of various pollutants into the groundwater.

Hardness is normally expressed as the total concentration of calcium and magnesium in $\mathrm{mg} / \mathrm{L}$, equivalent of $\mathrm{CaCO}_{3}$. According to Durfor and Becker's (1964) classification of TH, only one groundwater sample (W7) was moderately hard among the 14 sampling locations. The remaining groundwater samples were very hard (greater than $180 \mathrm{mg} / \mathrm{L}$ as $\mathrm{CaCO}_{3}$ ) in nature. Multivalent cations, particularly magnesium and calcium, are often present at a significant concentration in natural water. These ions are easily precipitated and in particular react with soap to make it difficult to remove scum. The calcium concentration in groundwater samples were beyond acceptable limit in two locations (W1 and W9). In most of the locations, magnesium content plays a major role and ranges between 7.2 and $81.6 \mathrm{mg} / \mathrm{L}$. The TA was higher than the acceptable limit of $200 \mathrm{mg} / \mathrm{L}$ as $\mathrm{CaCO}_{3}$ in all sampling locations. The high alkalinity imparts an unpleasant taste and may be
Fig. 3 Concentrations of $\mathrm{pH}$, EC, TDS, TA, and TH in groundwater samples
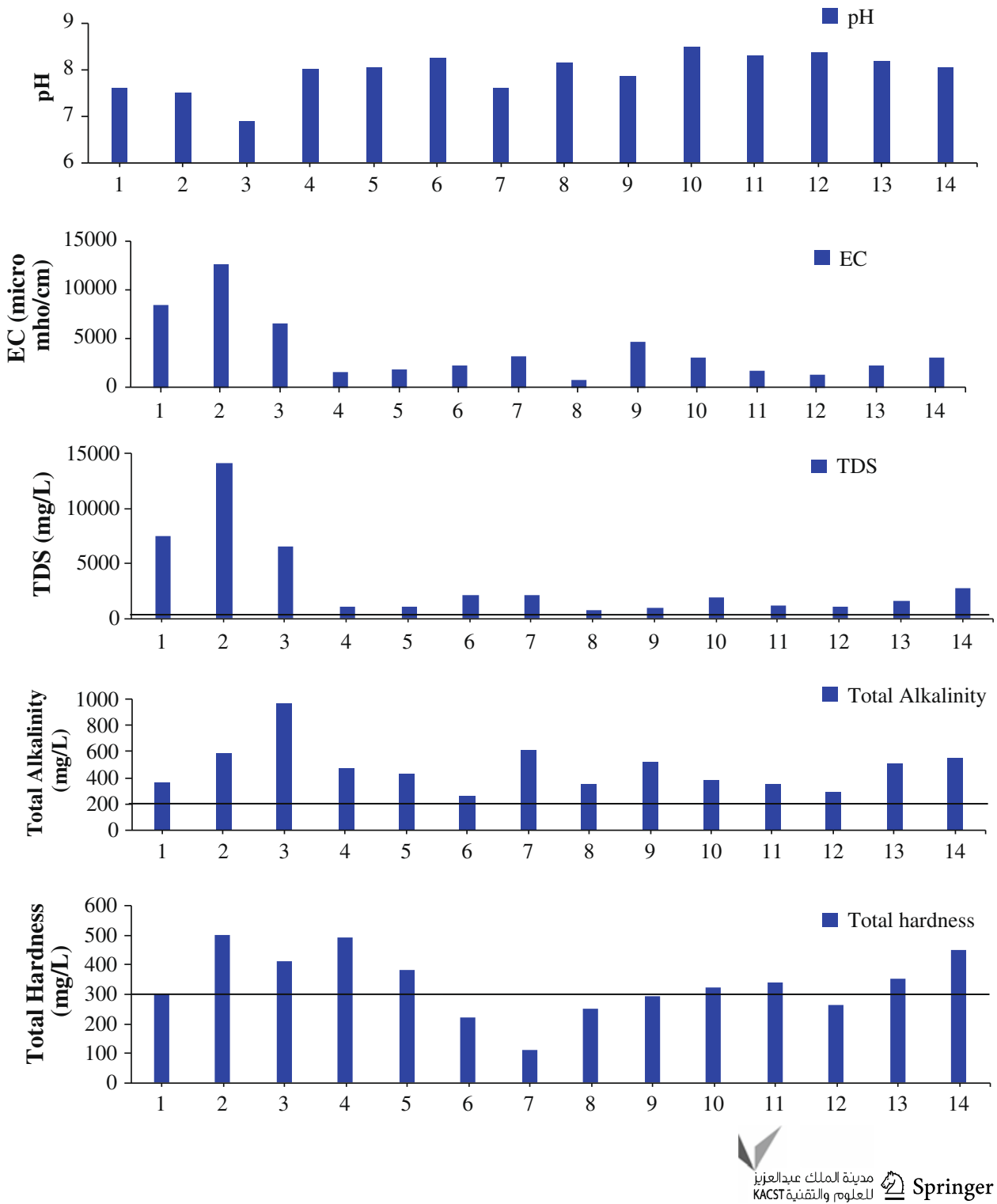
Fig. 4 Concentrations of $\mathrm{Ca}^{2+}$, $\mathrm{Mg}^{2+}, \mathrm{Cl}^{-}, \mathrm{SO}_{4}{ }^{2-}$, and $\mathrm{NO}_{3}{ }^{-}$in groundwater samples
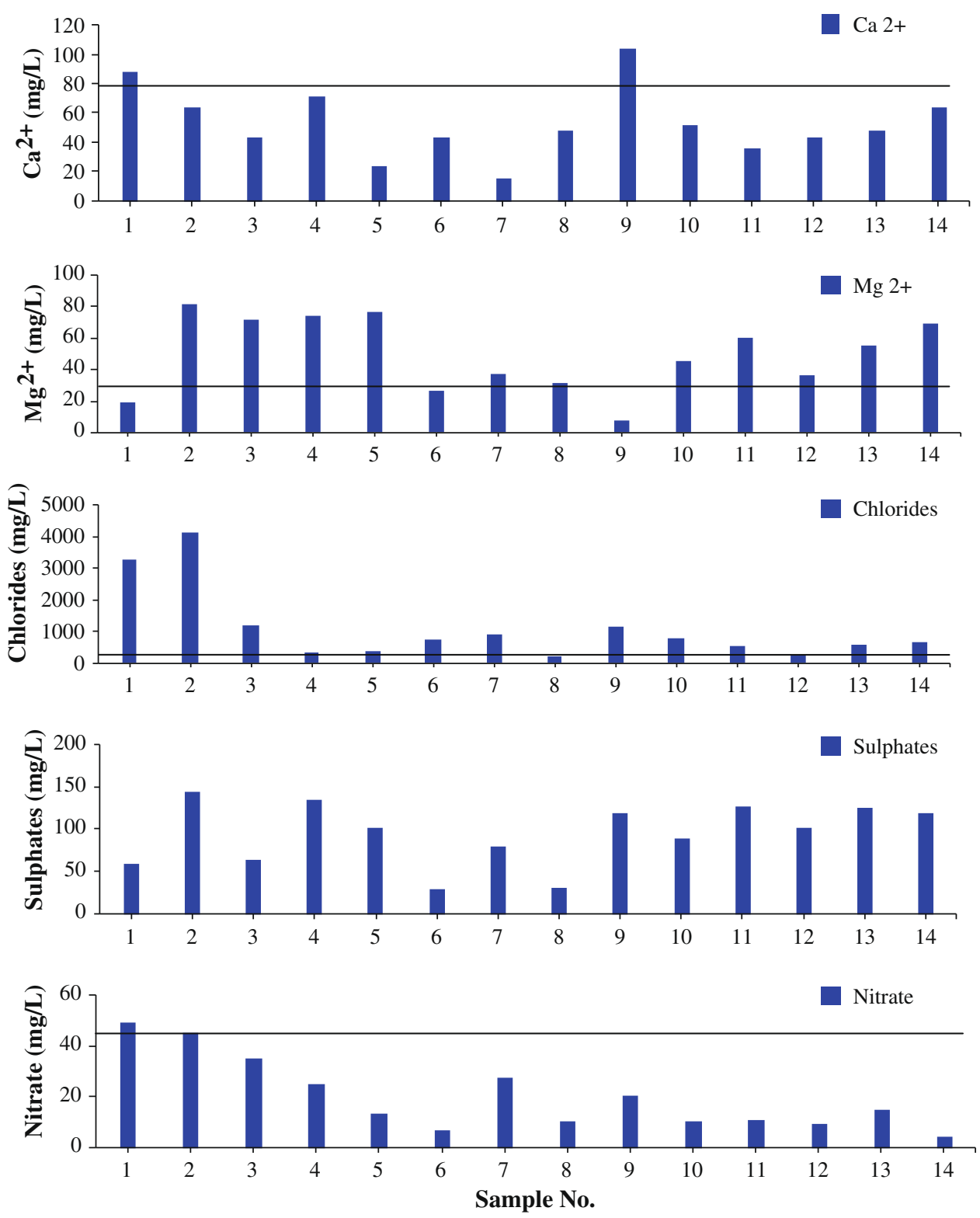

Fig. 5 Concentrations of TOC and iron in groundwater samples
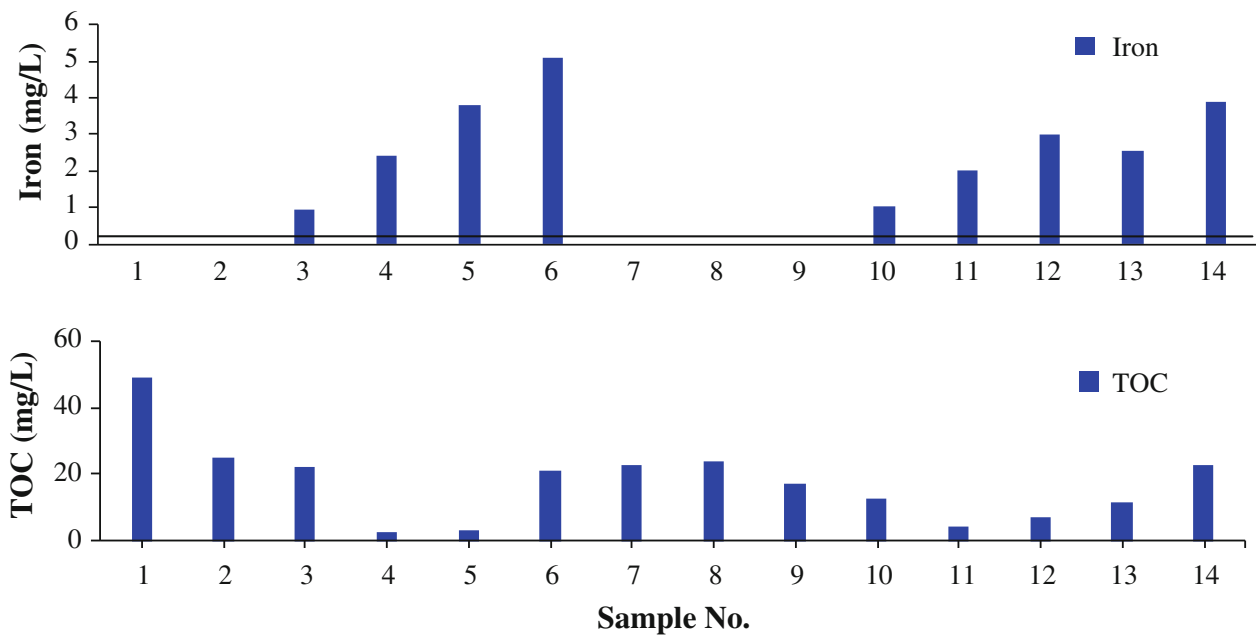
Fig. 6 Contour diagram of cadmium distribution profile in groundwater samples

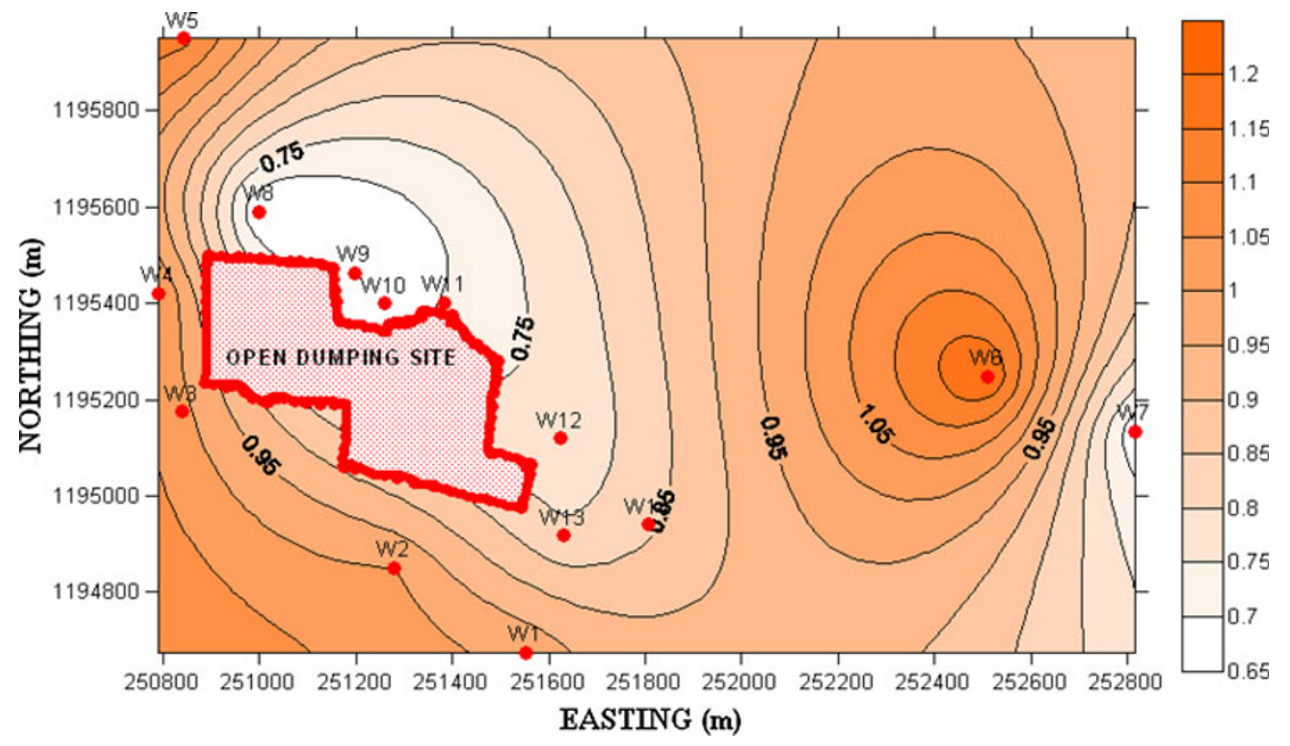

deleterious to human health along with the high $\mathrm{pH}$, TDS, and TH. Enhanced rock water interaction during postmonsoon could also contribute (to a limited extent) toward the increased values in bicarbonate (Pawar 1993).

The range of chlorides in all the locations under investigation is 215.15 (W8) to 4,098.73 (W2) $\mathrm{mg} / \mathrm{L}$. The concentration of chlorides in all locations except W8 exceeds the permissible level described by IS 10500-1991. Chloride in reasonable concentration is not harmful, but it causes corrosion in concentrations above $250 \mathrm{mg} / \mathrm{L}$, while at about $400 \mathrm{mg} / \mathrm{L}$, it causes a salty taste in water. An excess of chloride in water is usually taken as an index of pollution and considered as tracer for groundwater contamination (Loizidou and Kapetanios 1993). The chloride values in the water samples maybe due to the dissolution of rocks surrounding the aquifer and probably due to the leakage of sewage and anthropogenic pollution (agricultural activities). High concentration of chloride gives salty taste to water and may result in hypertension, osteoporosis, renal stones, and asthma (McCarthy 2004). The high chloride content in groundwater is from pollution sources such as domestic effluents, fertilizers, septic tanks, and leachates (Mor et al. 2006). Agricultural fertilizers and leachate are the main sources of sulfate in groundwater. The sulfate concentration in groundwater is within BIS and WHO standards for all the collected samples. Similarly, the nitrate concentration was also within the permissible limit $(45 \mathrm{mg} / \mathrm{L})$ in all the sampling locations except location 1 (W1). In general, the major sources for nitrate in groundwater include domestic sewage, runoff from agricultural fields, and leachate from landfill sites (Pawar and Shaikh 1995; Jawad et al. 1998; Lee et al. 2003; Jalali 2005). Higher concentration of $\mathrm{NO}_{3}{ }^{-}$in water causes a disease called "Methaemoglobinaemia" also known as "Blue-baby
Syndrome". This disease particularly affects infants that are up to 6 months old (Kapil et al. 2009). The presence of TOC values ranges from 2.7 to $49 \mathrm{mg} / \mathrm{L}$ indicates that the groundwater contains organic impurities. The concentration of $\mathrm{Fe}$ in the groundwater samples varies from below detectable limit (BDL) to $5.102 \mathrm{mg} / \mathrm{L}$ (Fig. 5) and was found to be well above the WHO permissible limit $(0.3 \mathrm{mg} / \mathrm{L})$ in all the samples. Presence of $\mathrm{Fe}$ in water can lead to change of color of groundwater (Rowe et al. 1995).

The contour diagrams show (Figs. 6, 7, 8, 9, 10) the concentration profile of heavy metals at several water sample locations near the study area. The contour diagrams were drawn by surfer software. The collected groundwater samples were analyzed for heavy metals such as $\mathrm{Cd}, \mathrm{Cu}$, $\mathrm{Mn}, \mathrm{Pb}$, and $\mathrm{Zn}$. Cadmium concentrations in the collected groundwater samples are lower than that of the leachate. The presence of cadmium concentration (Fig. 6) exceeds the permissible limit of $0.01 \mathrm{mg} / \mathrm{L}$ in all the collected samples. From the Fig. 6, it was observed that the contaminant species from the waste disposal site had migrated and accumulated at the location W6. Figure 7 shows the contour diagram of $\mathrm{Cu}$ distribution contaminant species from the location W3, it was located near an open dumping site toward southwest of the study area. From the Fig. 9, it was found that the presence of high concentration of $\mathrm{Pb}$ $(0.59 \mathrm{mg} / \mathrm{L})$ in groundwater samples nearby dumping site implies that groundwater samples were contaminated by leachate migration from an open dumping site. The concentrations of $\mathrm{Zn}$ (Fig. 10) in the collected samples were within the permissible limit.

Based on the contour diagram (from Figs. 6, 7, 8, 9, 10), the heavy metals such as lead $(\mathrm{Pb})$, manganese $(\mathrm{Mn})$, copper $(\mathrm{Cu})$, Cadmium $(\mathrm{Cd})$ showed significantly high values, which exceeded the maximum permissible 
Fig. 7 Contour diagram of copper distribution profile in groundwater samples

Fig. 8 Contour diagram of manganese distribution profile in groundwater samples

Fig. 9 Contour diagram of lead distribution profile in groundwater samples

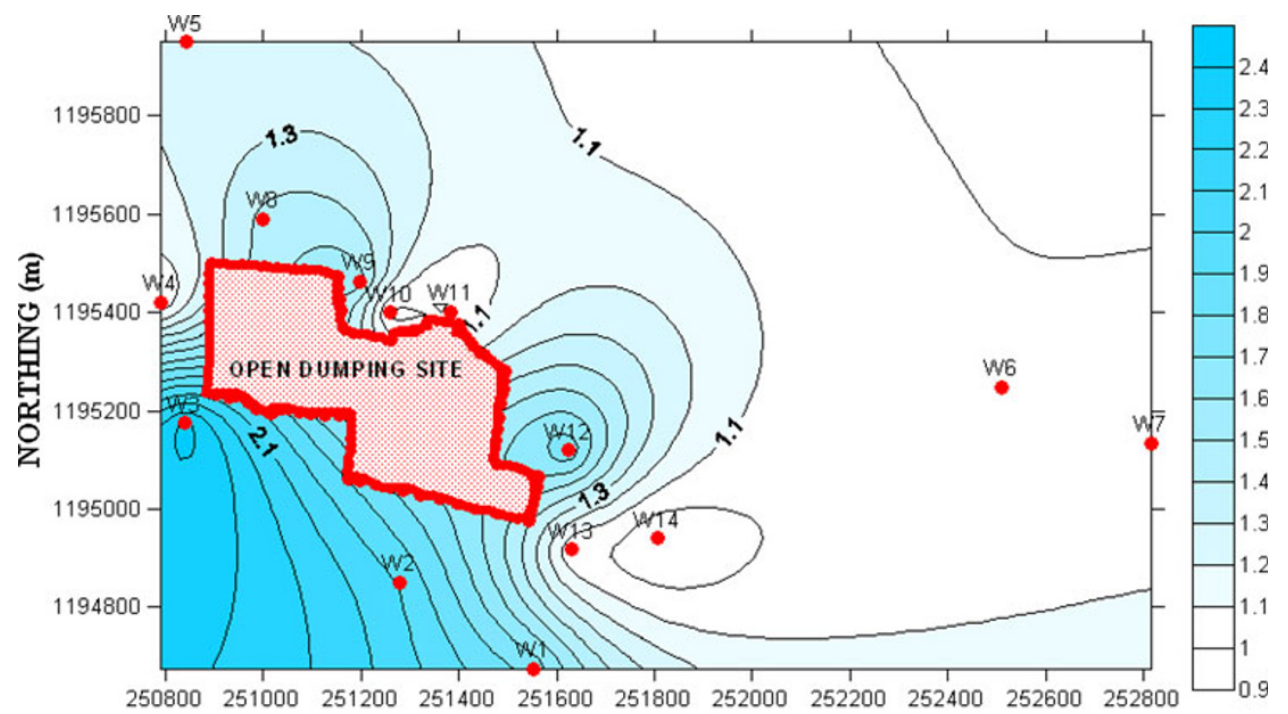

EASTING (m)
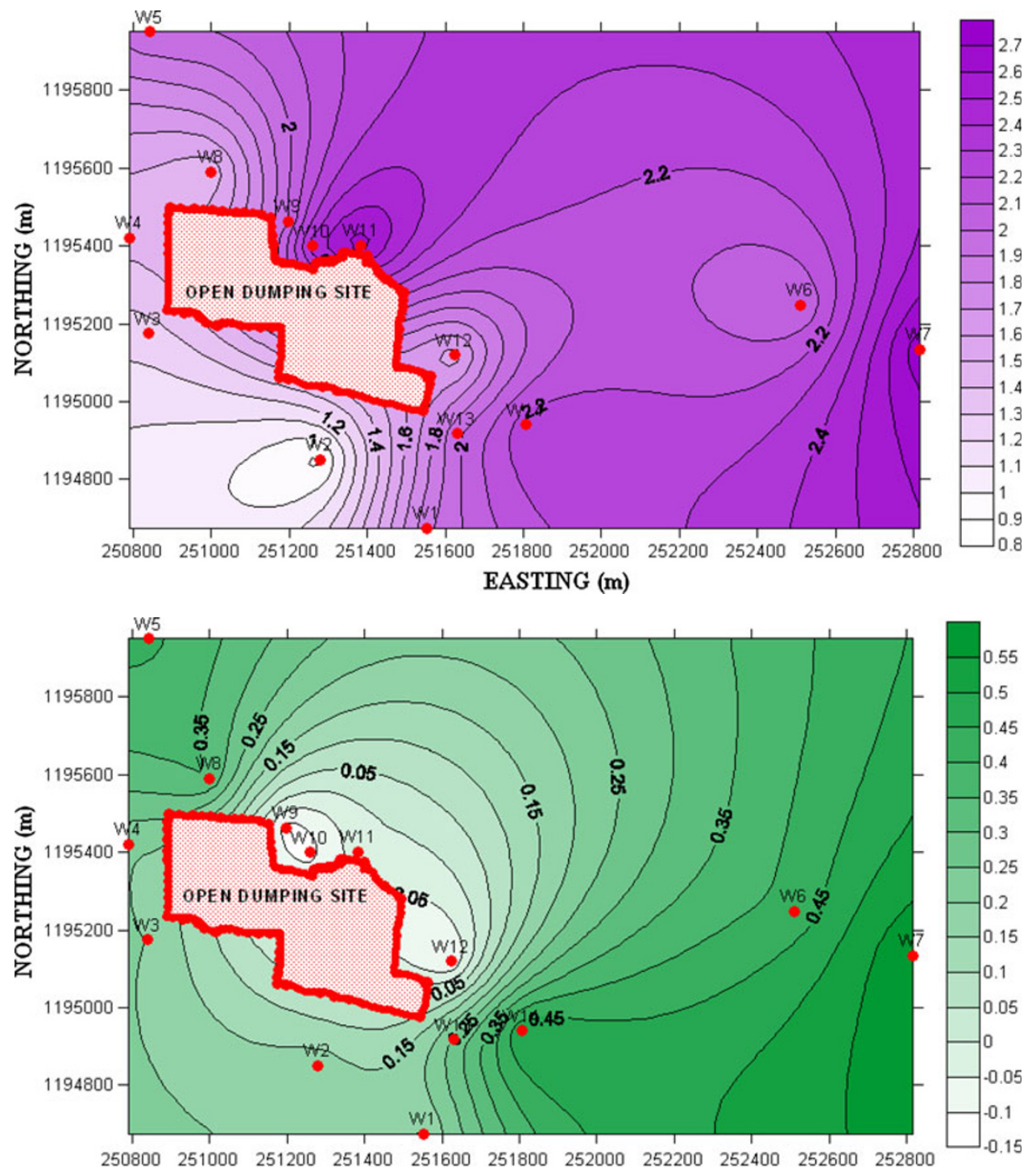

EASTING (m) 
Fig. 10 Contour diagram of zinc distribution profile in groundwater samples

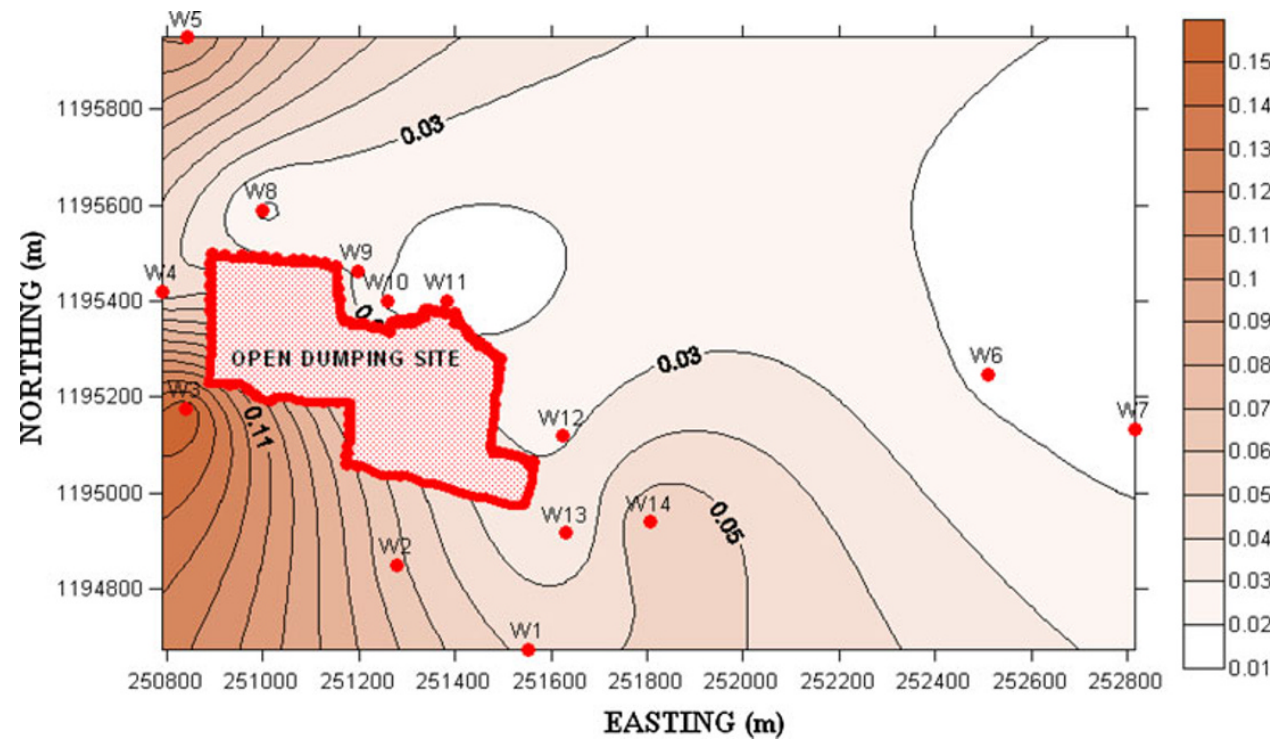

Table 4 Correlation matrix among ten water quality parameters of groundwater of study area

\begin{tabular}{|c|c|c|c|c|c|c|c|c|c|c|c|}
\hline & $\mathrm{pH}$ & $\mathrm{EC}$ & TDS & $\mathrm{TH}$ & TA & $\mathrm{Ca}^{2+}$ & $\mathrm{Mg}^{2+}$ & $\mathrm{HCO}_{3}{ }^{-}$ & $\mathrm{Cl}^{-}$ & $\mathrm{SO}_{4}{ }^{2-}$ & $\mathrm{NO}_{3}{ }^{-}$ \\
\hline $\mathrm{pH}$ & 1 & & & & & & & & & & \\
\hline EC & -0.679 & 1 & & & & & & & & & \\
\hline TDS & -0.750 & 0.748 & 1 & & & & & & & & \\
\hline $\mathrm{TH}$ & -0.378 & 0.111 & 0.039 & 1 & & & & & & & \\
\hline TA & -0.838 & 0.428 & 0.476 & 0.425 & 1 & & & & & & \\
\hline $\mathrm{Ca}^{2+}$ & -0.319 & 0.136 & 0.071 & 0.838 & 0.229 & 1 & & & & & \\
\hline $\mathrm{Mg}^{2+}$ & -0.332 & 0.061 & 0.001 & 0.882 & 0.485 & 0.482 & 1 & & & & \\
\hline $\mathrm{HCO}_{3}^{-}$ & -0.864 & 0.431 & 0.477 & 0.432 & 0.989 & 0.242 & 0.486 & 1 & & & \\
\hline $\mathrm{Cl}^{-}$ & -0.535 & 0.964 & 0.704 & 0.077 & 0.201 & 0.157 & -0.012 & 0.217 & 1 & & \\
\hline $\mathrm{SO}_{4}^{2-}$ & 0.085 & 0.165 & -0.238 & 0.155 & 0.145 & -0.032 & 0.276 & 0.139 & 0.123 & 1 & \\
\hline $\mathrm{NO}_{3}^{-}$ & -0.778 & 0.844 & 0.770 & 0.287 & 0.449 & 0.333 & 0.173 & 0.469 & 0.833 & 0.067 & 1 \\
\hline
\end{tabular}

concentration (MPC) as specified by WHO and BIS Standards for drinking water. Meanwhile, the zinc ( $\mathrm{Zn})$ was detected below the (MPC) value. The results indicated that all the collected sample locations were rigorously affected by the migration of leachate. Hence, the water is not potable for drinking purpose.

Correlation analysis for different water quality parameters

Correlation is a method used to evaluate the degree of interrelation and association between two variables (Nair et al. 2005). A correlation of +1 indicates a perfect positive relationship between two variables. A correlation of -1 indicates that one variable changes inversely with relation to the other. A correlation of zero indicates that there is no relationship between the two variables (Kapil et al. 2009).
Table 4 represents the correlation matrix among ten water quality parameters of groundwater of the study area.

Electrical conductivity and $\mathrm{Cl}^{-}$show good positive correlation with major water quality parameters. The correlation $(r=0.964, p \leq 0.01)$ between these two parameters for the analyzed samples in this study show a linear correlation. Equally, TA and $\mathrm{HCO}_{3}{ }^{-}(r=0.989, p \leq 0.01)$ indicate the good positive correlation. Some of the other highly significant and positive correlation were found between $\mathrm{EC}-\mathrm{NO}_{3}{ }^{-}(r=0.844, p \leq 0.01)$, EC-TDS $(r=0.748, p \leq 0.01)$, TDS- $-\mathrm{HCO}_{3}{ }^{-}(r=0.477, p<$ $0.01), \quad \mathrm{TDS}-\mathrm{Cl}^{-}(r=0.704, p \leq 0.01), \quad \mathrm{TDS}-\mathrm{NO}_{3}{ }^{-}$ $(r=0.770, p \leq 0.01)$, which also shows linear correlation. This suggested that presence of bicarbonate; chloride and nitrate in the study area greatly influence the TDS and EC. TH was also positively and significantly correlated with TA $(r=0.425, p \leq 0.01), \mathrm{HCO}_{3}^{-}(r=0.432, p \leq 0.01)$, 
$\mathrm{SO}_{4}{ }^{2-}(r=0.155, p \leq 0.01), \mathrm{Ca}^{2+}(r=0.838, p \leq 0.01)$ and $\mathrm{Mg}^{2+}(r=0.882, p \leq 0.01)$. This result implies that there was great dependence of hardness on calcium, magnesium, chloride, sulfate, and bicarbonate. $\mathrm{pH}$ was negatively correlated with all the parameters except $\mathrm{SO}_{4}{ }^{2-}$. Similarly few other parameters were also found to have negative correlation, viz TDS- $\mathrm{SO}_{4}{ }^{2-}(r=-0.238)$, $\mathrm{Ca}^{2+}-\mathrm{SO}_{4}{ }^{2-}(r=-0.032)$ and $\mathrm{Mg}^{2+}-\mathrm{Cl}^{-}(r=-0.012)$. $\mathrm{EC}$ is solely a function of the major ion concentrations $\left(\mathrm{Ca}^{2+}, \mathrm{Mg}^{2+}, \mathrm{Cl}^{-}, \mathrm{SO}_{4}{ }^{2-}\right.$, and $\left.\mathrm{NO}_{3}{ }^{-}\right)$of water quality parameters. The result was compared with the study reported by Kapil et al. (2009) for Indian conditions. They revealed that the major positive linear correlation was found in EC with all the water quality parameters in their study area.

\section{Conclusion}

The indiscriminate disposal and crude dumping of MSW are considered as a dangerous practice in integrated waste management at the global level. The fresh solid waste composition study shows that samples from the open dump site contained about 90-95\% combustible materials and non-combustible fraction is about $1-5 \%$. The fresh leachate sample possesses very high concentration of chemical parameters except $\mathrm{pH}$, when compared to stabilized leachate samples. The heavy metal concentration range of collected fresh leachate sample showed a higher degree of metal solubilization when compared to stabilized leachate samples. The $\mathrm{pH}$ values of all groundwater samples are within the range of BIS and WHO standards. The physicochemical analysis indicated that chlorides (range between 215.15 and $4,098.73 \mathrm{mg} / \mathrm{L}$ ) and TDS (ranges from 740 to $14,200 \mathrm{mg} / \mathrm{L}$ ) of the groundwater samples are higher than the permissible limits in all the sampling locations when compared to other parameters. The presence of heavy metals $(\mathrm{Pb}, \mathrm{Mn}, \mathrm{Cu}, \mathrm{Cd}$ and $\mathrm{Zn})$ in groundwater samples indicates that there is appreciable contamination by leachate migration from an open dumping site. Based on the average concentration, the heavy metal components in the groundwater samples were found in the following order: $\mathrm{Pb}>\mathrm{Mn}>\mathrm{Cu}>\mathrm{Cd}>\mathrm{Zn}$. From the present study, it was found that the groundwater is non-potable because most of the physicochemical parameters and heavy metals examined exceed the permissible limits. Ultimately, all results presented show that the Ariyamangalam open dump site constitutes a serious threat to local aquifers. The details such as solid waste composition, leachate characteristics and characteristics of groundwater samples will be used to develop contaminant transport model using Visual MODFLOW and MT3DMS software for leachate migration into subsurface system from open dumping site.
Acknowledgments We sincerely thank the Department of Science and Technology, New Delhi for the financial support rendered to carry out the research work. We also thank the Corporation of Tiruchirappalli for the permission to carry out the studies at the open dump sites.

Open Access This article is distributed under the terms of the Creative Commons Attribution License which permits any use, distribution, and reproduction in any medium, provided the original author(s) and the source are credited.

\section{References}

Ahmed AM, Sulaiman WN (2001) Evaluation of groundwater and soil pollution in a landfill area using electrical resistivity imaging survey. Environ Manag 28:655-663

Akoteyon IS, Mbata UA, Olalude GA (2011) Investigation of heavy metal contamination in groundwater around landfill site in a typical sub-urban settlement in Alimosho Lagos-Nigeria. J Appl Sci Environ Sanit 6(2):155-163

Alker SC, Sarsby RW, Howell R (1995) Composition of leachate from waste disposal sites. In: Proceedings waste disposal by landfill-Green 1993, Balkemia, pp 215-221

Al-Yaqout AF (2003) Assessment and analysis of industrial liquid waste and sludge disposal at unlined landfill sites in arid climate. Waste Manag (Oxford) 23:817-824

Andrew AA, Jun S, Takahiro H, Kimpei I, George EN, Wilson YF, Gloria ETE, Ntankouo NR (2011) Evaluation of groundwater quality and its suitability for drinking domestic and agricultural uses in the Banana Plain (Mbanga Njombe Penja) of the Cameroon Volcanic Line. Environ Geochem Health 33:559-575

APHA (1998) Standard methods for the examination of water and wastewater (17th ed). American Public Health Association, Washington

Armon R, Kitty (1994) The Health dimension of groundwater contamination. In: Holler (ed) Groundwater contamination and control. Marcel Dekker Inc, New York

Babiker SI, Mohamed AA, Mohamed TH (2007) Assessing groundwater quality using GIS. Water Resour Manag 21:699-715

Bagchi A (2004) Design of landfills and integrated solid waste management. Wiley, New Jersey

Bjerg PL, Rugge K, Pedersen JK, Christensen TH (1995) Distribution of redox-sensitive groundwater quality parameters downgradient of a landfill (Grindsted Denmark). Environ Sci Technol 29:1387-1394

Bureau of Indian Standards (BIS):1991 Indian standard specification for drinking water IS: $105002-4$

Calli B, Mertoglu B, Inanc B (2005) Landfill leachate management in Istanbul: applications and alternatives. Chemosphere 59:819-829

Cariera C, Masciopinto C (1998) Assessment of groundwater after leachate release from landfills. Anal Chim 88:811-818

Chapman D (1992) A guide to the use of BIOTA sediments and water in environmental monitoring water quality assessments UNESCO/WHO/UNEP. Chapman and Hall, London, pp 371-460

Chu LM, Cheung KC, Wong MH (1994) Variations in the chemical properties of landfill leachate. Environ Manag 18:105-117

Denutsui D, Akiti TT, Osae S, Tutu AO, Blankson-Arthur S, Ayivor JE, Adu-Kwame FN, Egbi C (2012) Leachate characterization and assessment of unsaturated zone pollution near municipal solid waste landfill site at Oblogo Accra-Ghana. Res J Environ Earth Sci 4(1):134-141

Dong S, Liu B, Tang Z (2008) Investigation and modeling of the environment impact of landfill leachate on groundwater quality at Jiaxing Southern China. J Environ Technol Eng 1(1):23-30 
Durfor CN, Becker E (1964) Public water supplies of the 100 largest cities in the United States. US Geographical Survey of Water Supply Paper, pp 1812

El-Fadel M, Bou-Zeid E, Chahine W, Alayli B (2002) Temporal variation of leachate quality from pre-sorted and baled municipal solid waste with high organic and moisture content. Waste Manag (Oxford) 22:269-282

Fatta D, Papadopoulos A, Loizidou M (1999) Evaluation of groundwater and soil pollution in a landfill area using electrical resistivity imaging survey. Environ Geochem Health 21:175-190

Freeze RA, Cherry JA (1979) Ground water. Prentice-Hall, Englewood Cliffs

Gallorini M, Pesavento M, Profumo A, Riolo C (1993) Analytical related problems in metal and trace elements determination in industrial waste landfill leachates. Sci Total Environ 133:285-298

Gidarakos E, Havas G, Ntzamilis P (2005) Municipal solid waste composition determination supporting the integrated solid waste management system in the island of Crete. Waste Manag 26(6):668-679

Jalali M (2005) Nitrate leaching from agricultural land in Hamadan western Iran. Agric Ecosyst Environ 110:210-218

Jawad A, Al-Shereideh SA, Abu-Rukah Y, Al Qadat K (1998) Aquifer ground water quality and flow in the Yarmouk River Basin of Northern Jordan. Environ Syst 26:265-287

Jhamnani B, Singh SK (2009) Groundwater contamination due to Bhalaswa landfill site in New Delhi. Int $\mathrm{J}$ Environ Sci Eng 1(3):121-125

Joseph Kurian, Rajendiran S, Senthilnathan R, Rakesh M (2012) Integrated approach to solid waste management in Chennai: an Indian metro city. J Mater Cycles Waste Manag 14:75-84

Kale SS, Ajay KK, Kumar Suyash, Pawar NJ (2010) Evaluating pollution potential of leachate from landfill site from the Pune metropolitan city and its impact on shallow basaltic aquifers. Environ Monit Assess 162:327-346

Kapil DM, Mamta K, Sharma DK (2009) Hydrochemical analysis of drinking water quality of Alwar District Rajasthan. Nature Sci 7(2):30-39

Khan R, Husain T, Khan HU, Khan SM, Hoda A (1990) Municipal solid waste management-a case study. Munic Eng 7:109-116

Kjelsen P, Bjerg PL, Rugge K, Christensen TH, Pedersen JK (1998) Characterization of an old municipal landfill (Grindsted Denmark) as a groundwater pollution source: landfill hydrology and leachate migration. Waste Manag Res 16:14-22

Koussis AD, Syriopoulou D, Ramanujam G (1989) Computation of three-dimensional advection-dominated transport in saturated aquifers. US Government Report

Kunkle GR, Shade JW (1976) Monitoring groundwater quality near a sanitary landfill. Groundwater 14:11-20

Lee KK, Kim YY, Chang HW, Chung SY (1997) Hydrogeological studies on the mechanical behaviour of landfill gases and leachate of the Nanjido Landfill in Seoul Korea. Environ Geol 31:185-198

Lee SM, Min KD, Woo NC, Kim YJ, Ahn C (2003) Statistical assessment of nitrate contamination in urban groundwater using GIS. Environ Geol 44:210-221
Lo IMC (1996) Characteristics and treatment of leachates from domestic landfills. Environ Int 22(4):433-442

Loizidou M, Kapetanios EG (1993) Effect of leachate from landfills on groundwater quality. Sci Total Environ 128:69-81

McCarthy MF (2004) Should we restrict chloride rather than sodium? Med Hypotheses 63:138-148

McCreanor PT, Reinhart DR (2000) Mathematical modeling of leachate routing in a leachate recirculating landfill. Water Res 34:1285-1295

Mohan S, Gandhimathi R (2009) Solid waste characterisation and the assessment of the effect of dumping site leachate on groundwater quality: a case study. Int J Environ Waste Manag 3(1/2):65-77

Mor S, Ravindra K, Dahiya RP, Chandra A (2006) Leachate characterization and assessment of groundwater pollution near municipal solid waste landfill site. Environ Monit Assess 118:435-456

Nair GA, Mohamed AI, Premkumar K (2005) Physico chemical parameters and correlation coefficents of ground waters of North-East Libya. Pollut Res 24(1):1-6

Norusis MJ (1997) SPSS Inc SPSS for Windows Professional Statistics 75. Prentice Hall, Englewood Cliffs

Ostendorf DW, Noss RR, Lederer DO (1984) Landfill leachate migration through shallow unconfined aquifers. Water Resour Res 20:291-296

Pawar NJ (1993) Geochemistry of carbonate precipitation from the ground waters in basaltic aquifers: an equilibrium thermodynamic approach. J Geol Soc India 41:119-131

Pawar NJ, Shaikh IJ (1995) Nitrate pollution of groundwater from shallow basaltic aquifers Deccan trap hydrologic province India. Environ Geol 25:197-204

Rabinove CJ, Long Ford RH, BrookHart JW (1958) Saline water resource of North Dakota. US geological survey of water supply paper 1428:72

Robinson H, Gronow J (1992) Groundwater protection in the UK: assessment of the landfill leachate source-term. Institute of Water Engineers and Managers 6:229-236

Rowe RK, Quigley RQ, Booker JR (1995) Clay barrier systems for waste disposal facilities. E and FN Spon, London

Sabahi AE, Abdul Rahim S, Wan Zuhairi WY, Fadhl AN, Fares A (2009) The characteristics of leachate and groundwater pollution at municipal solid waste landfill of Ibb City Yemen American. J Environ Sci 5(3):256-266

Syriopoulou D, Koussis AD (1987) Two-dimensional modeling of advection dominated solute transport in groundwater. Hydrosoft $1: 63-70$

Visvanathan C, Trankler J, Joseph K, Chiemchaisri C, Basnayake BFA, Gongming Z (2004) Municipal solid waste management in Asia. Asian Regional Research Program on Environmental Technology (ARRPET). Asian Institute of Technology publications. ISBN: 974:417-258-1

World Health Organization (WHO) (2002) Guideline for drinking water quality. Health criteria and other supporting information. World Health Organization, Geneva, pp 940-949 